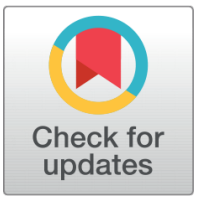

OPEN ACCESS

Received: 29-05-2020

Accepted: $12-08-2020$

Published: 15-09-2020

Editor: Dr. Natarajan Gajendran

Citation: Memon OA, Soomro AM, Kumar M, Farhan M (2020) Implementation of microgrid with integration of hybrid renewable sources using different backup techniques. Indian Journal of Science and Technology 13(33): 3457-3466. https://doi.org/ 10.17485/IJST/v13i33.763

*Corresponding author. owaismemon922@gmail.com

Funding: None

Competing Interests: None

Copyright: @ 2020 Memon et al. This is an open access article distributed under the terms of the Creative Commons Attribution License, which permits unrestricted use, distribution, and reproduction in any medium, provided the original author and source are credited.

Published By Indian Society for Education and Environment (iSee)

ISSN

Print: 0974-6846

Electronic: 0974-5645

\section{Implementation of microgrid with integration of hybrid renewable sources using different backup techniques}

\author{
Owais Ahmed Memon ${ }^{1 *}$, Amir Mahmood Soomro ${ }^{1}$, Mahesh Kumar ${ }^{1}$, \\ Muhammad Farhan ${ }^{2}$ \\ 1 Institute of Information and Communication Technologies, Mehran University of \\ Engineering and Technology, Jamshoro, Pakistan \\ 2 Department of Electrical Engineering, Government College University, Faisalabad, Pakistan
}

\section{Abstract}

Background/Aim: This research aims to design and compare four Hybrid Microgrid Systems involving different backup techniques for a remote village in Sindh, Pakistan and finds the most optimal hybrid system based on Net Present Cost (NPC) and Cost of Electricity (COE). Methods/Statistical analysis: In order to make a suitable hybrid system, firstly, a proper literature review was done to get the information about the recent work done on this system after that four hybrid systems were designed with two common primary sources: Solar and Wind and different backup sources including Batteries, Fuel Cell, Diesel Generator and Gird. HOMER performed optimization on all four hybrid system cases based on NPC and COE to find the most optimal hybrid system for each case. Findings: The comparison of all four optimal hybrid cases shows that Solar/Wind/Grid Hybrid Microgrid System is the most optimal system for that location with NPC PKR $21 \mathrm{M}$ and COE PKR 12.84. The payback period of this system is 3 years. This research is based on real-time data and involves the comparison of four different hybrid systems to find an optimal hybrid system. Novelty/Applications: The world is greatly moving towards renewables keeping in view their enormous benefits and the current global warming issue. Pakistan is one of those countries who are blessed with an abundant renewable resource, which if utilized properly then it can fulfil the whole country's energy demand, and this will also reduce the use of fossil fuels in the energy sector of the country.

Keywords: Microgrid; hybrid renewable sources; optimazation; net preent cost (NPC); cost of electricity (COE); renewable fraction (RF)

\section{Introduction}

Electricity has become a basic need for living in today's world, from home to every small or large business today depends on electricity. Electricity has a vital role in the 
country's development and economy. This electricity demand is increasing globally with an annual average growth rate of $2.3 \%$ due to the increase in the population worldwide ${ }^{(1)}$. The use of fossil fuels to generate this electricity is becoming a major issue due to diminishing resources, expensive fuel prices and environmental concerns. These issues are the major reasons behind the growing popularity of renewable energy sources. The world is moving rapidly towards renewables because of their enormous benefits like they are environment-friendly, have least fuel cost and electricity is also cheaper than that of fossil fuels. The main drawback of renewable sources is they are intermittent by nature but with the advancement of new technologies, these sources can now be integrated to make a hybrid system ${ }^{(2)}$.

The two most common renewables sources being used worldwide are Solar and Wind but they both lack in producing continuous power as they both depend on nature that is why their combination makes a suitable and reliable hybrid system and some means must be provided for storing the generated electricity from these sources like batteries, fuel cell or a grid can be integrated with these sources for backup supply. Pakistan is one of those countries who are blessed with enough renewable energy potential, with $300+$ sunny days, tremendous wind speed in some areas especially coastal areas of Sindh and many other resources are also available which can be utilized to meet country's energy demand ${ }^{(2)}$. Despite having enough renewable potential, Pakistan is generating $62 \%$ of its electricity from fossil fuels as can be seen in Figure ${ }^{(3)}$. Pakistan being a developing country is facing energy crisis for the last 20 years and the supply and demand gap is increasing since that. This causes the load shedding especially on rural areas to meet the demand of urban areas. This load shedding has been increased up to $10 \mathrm{~h}$ in summer and $6 \mathrm{~h}$ in winter. This daily power outage is one of the main reasons for the country's lower GDP ${ }^{(4)}$.

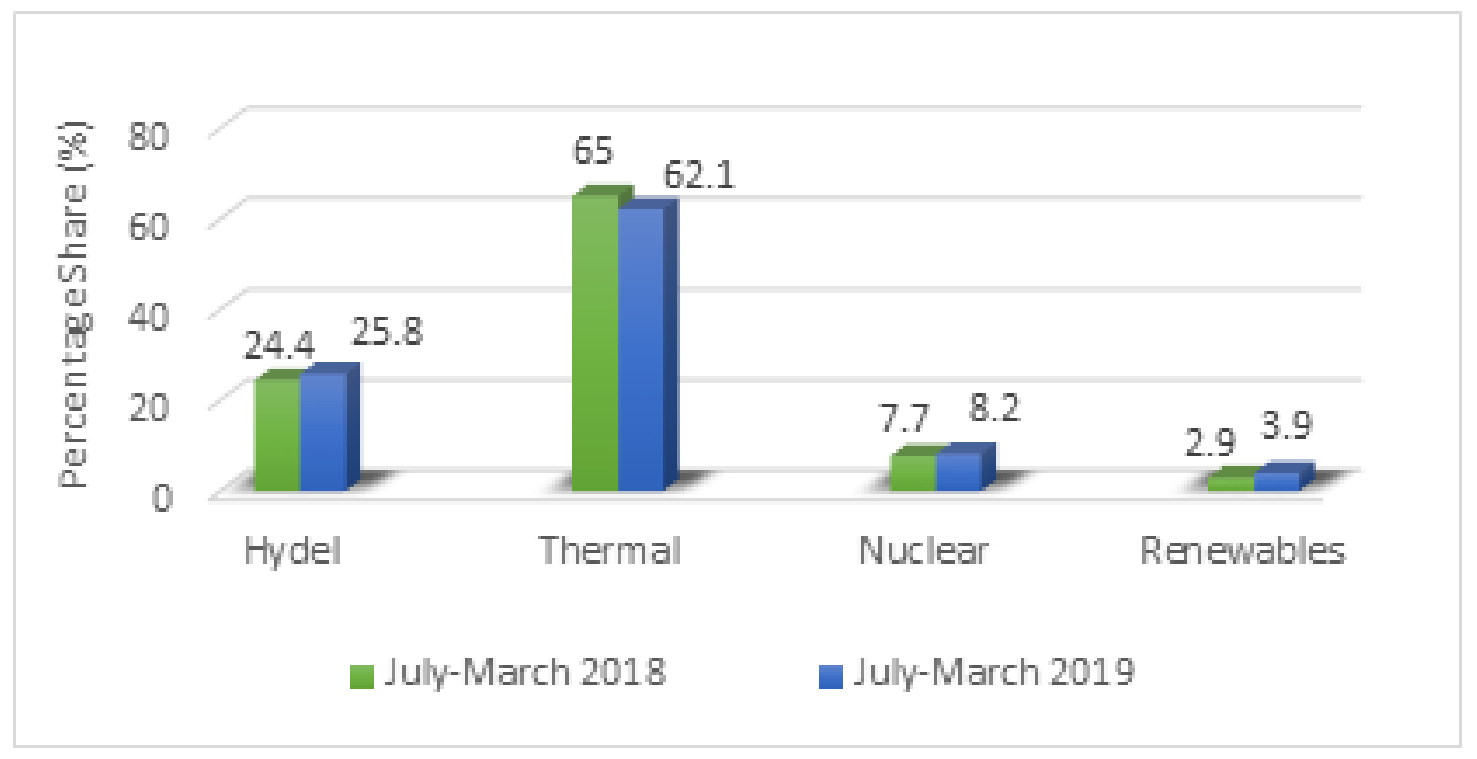

Fig 1. Pakistan's energy mix scenario chart ${ }^{(3)}$

HOMER Software has been used by many researchers to design different microgrid models and to perform different tasks like finding feasibility or doing cost analysis etc. A feasibility study was carried out of a hybrid microgrid system containing WTG, Diesel Generator (DG) and battery on the basis of technical and economical parameters. The system was tested with different types of batteries like Lead Acid, Lithium Ion, Zinc Bromine (ZB) etc. to find the optimal system for a residential community with 280 houses, located in Gansu, China. The results indicate that hybrid system containing DG and ZB Batteries is the most optimal system with $1460 \mathrm{~kW}$ DG, $500 \mathrm{ZB}$ Batteries and a $400 \mathrm{~kW}$ Converter. This optimal hybrid system has NPC of $\$ 7,735646$ and COE of $\$ 0.47 / \mathrm{kWh}^{(5)}$.

A standalone system was designed using single renewable energy source Solar PV with battery storage for a typical rural house in Punjab, Pakistan. The average daily consumption of that rural house was calculated to be $10 \mathrm{kWh} /$ day. HOMER Software was used to find the optimal solution for that house ${ }^{(4)}$. Another feasibility study was carried out on a standalone Solar PV-Biogas hybrid system for a small village of a Cholistan Community. The village had more than 80 houses. Two load profiles were considered one for local consumption other for agriculture need and according to that a model was developed and HOMER Software was used to find the optimal solution for that village ${ }^{(6)}$. 


\section{Methodology}

\subsection{Study area}

A village named as Saeedpur Takkar near Mulaqatiar Road Tando Muhammad Khan, Sindh is selected for the case study as shown in Figure 2. This village is located at the latitude $25.1326^{\prime} \mathrm{N}$ and longitude $68.4539^{\prime} \mathrm{E}^{(7)}$. It consists around 85 houses, some shops and a secondary school. The houses in rural areas, unlike urban areas, are scattered. This location is chosen because it is rich in renewable resources like solar and wind.

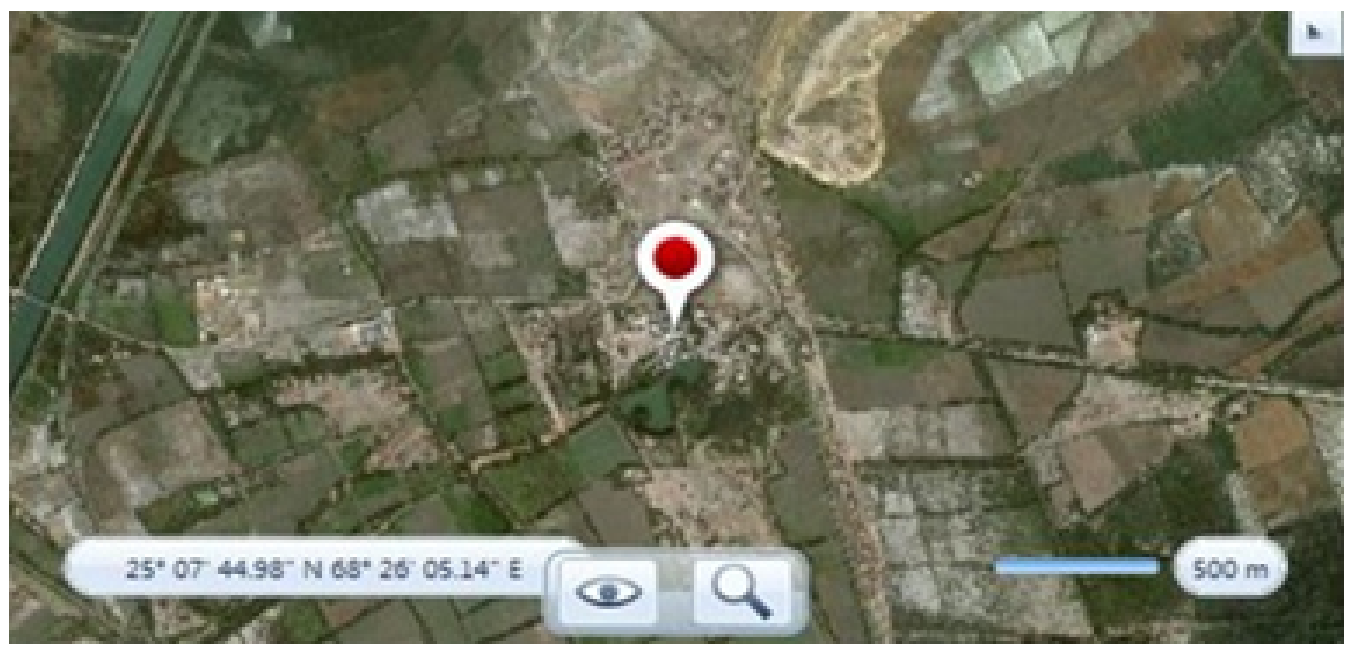

Fig 2. Saeedpur Takkar Village (7) $^{(7)}$

\subsection{Resource assessment}

\subsubsection{Solar data}

The horizontal global solar irradiation for the selected location is obtained from NASA Surface Meteorology and Solar Energy Database $^{(8)}$. The maximum average solar irradiation obtained for the selected location is $6.86 \mathrm{kWh} / \mathrm{m} 2 /$ day in the month of May and the annual average solar irradiation is $5.38 \mathrm{kWh} / \mathrm{m} 2 /$ day as can be seen in Figure 3.

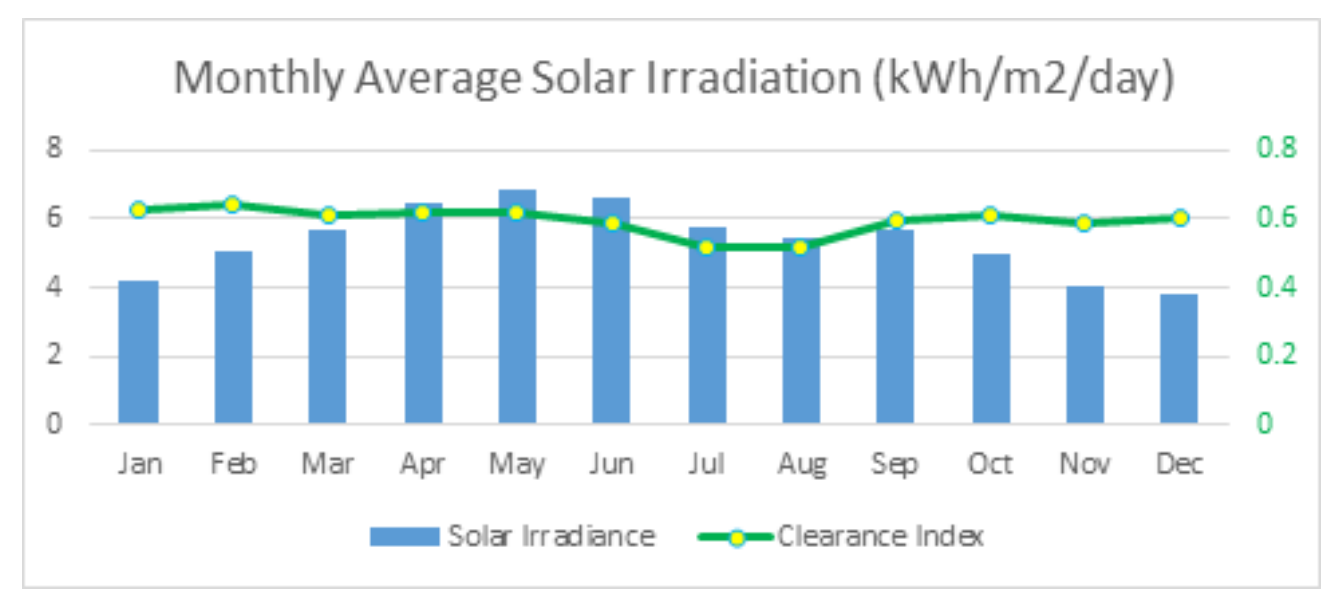

Fig 3. Monthly solar irradiation data ${ }^{(8)}$ 


\subsubsection{Wind data}

The wind speed data for the selected location is obtained from NASA Surface Meteorology and Solar Energy Database ${ }^{(8)}$. The maximum average wind speed obtained for the selected location is $9.6 \mathrm{~m} / \mathrm{s}$ in the month of June and the annual average wind speed is $5.86 \mathrm{~m} / \mathrm{s}$ as can be seen in Figure 4 . In our study turbine height is considered $25 \mathrm{~m}$ to $30 \mathrm{~m}$, HOMER will convert these values from $50 \mathrm{~m}$ anemometer height to $25 \mathrm{~m}$ turbine height.

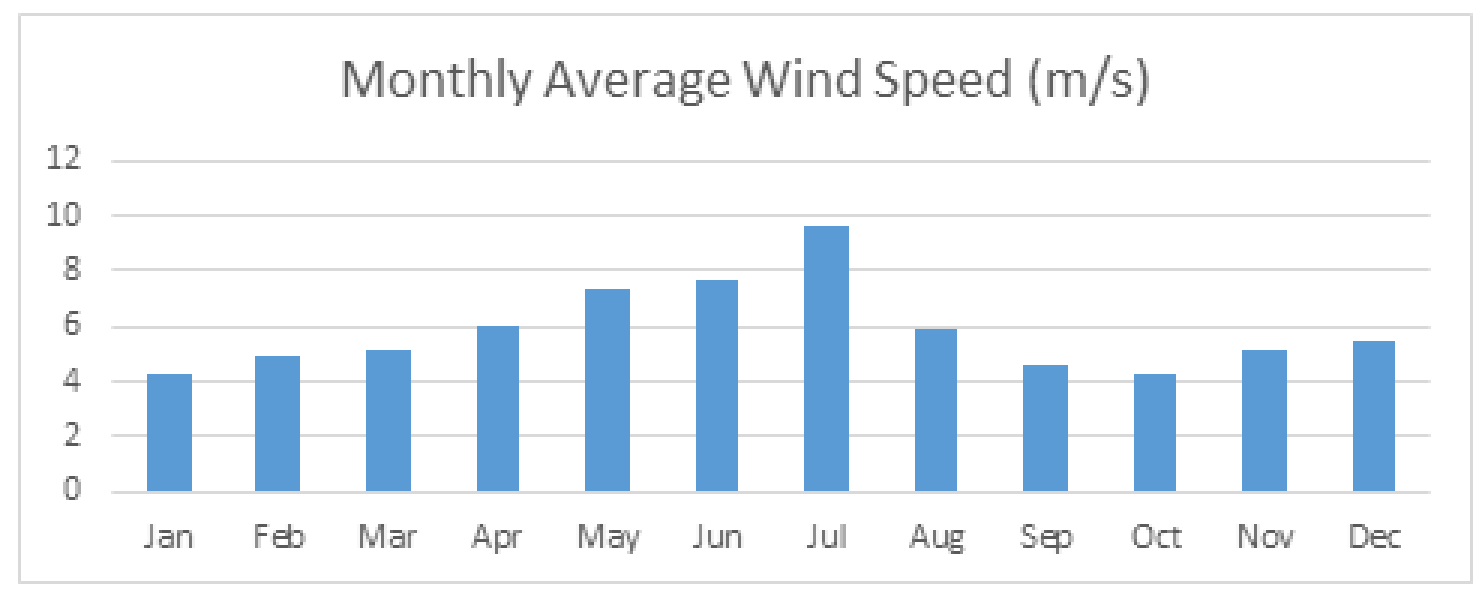

Fig 4. Monthly wind speed data ${ }^{(8)}$

\subsection{Load assessment}

The load survey was conducted on the selected village and the data was collected from each consumer. The total average daily consumption of the whole village was calculated very carefully keeping in view the total operating hours and seasonal load growth and reduction.

Table 1. Load data

\begin{tabular}{|c|c|c|c|c|c|c|c|}
\hline Load Type & Appliances & $\begin{array}{l}\text { Power } \\
\text { (Watts) }\end{array}$ & Quantity & $\begin{array}{l}\text { Total Power } \\
\text { (Watts) }\end{array}$ & $\begin{array}{l}\text { Operation } \\
\text { Hours (h) }\end{array}$ & $\begin{array}{l}\text { Energy Con- } \\
\text { sumption (Wh) }\end{array}$ & $\begin{array}{l}\text { Total Consumption } \\
(\mathrm{kWh} / \text { day })\end{array}$ \\
\hline \multirow[t]{5}{*}{ Household } & Lights & 12 & 3 & 36 & 6 & 216 & 4.73 \\
\hline & Fan & 50 & 2 & 100 & 24 & 2400 & \\
\hline & Refrigerator & 60 & 1 & 60 & 24 & 1440 & \\
\hline & TV & 50 & 1 & 50 & 4 & 200 & \\
\hline & Misc. & 20 & 1 & 20 & 24 & 480 & \\
\hline \multirow[t]{4}{*}{ Shop } & Lights & 12 & 2 & 24 & 4 & 96 & 3.67 \\
\hline & Fan & 50 & 1 & 50 & 14 & 700 & \\
\hline & Refrigerator & 100 & 1 & 100 & 24 & 2400 & \\
\hline & Misc. & 20 & 1 & 20 & 24 & 480 & \\
\hline \multirow[t]{3}{*}{ School } & Lights & 12 & 10 & 120 & 6 & 720 & 4.2 \\
\hline & Fan & 50 & 10 & 500 & 6 & 3000 & \\
\hline & Misc. & 20 & 1 & 20 & 24 & 480 & \\
\hline
\end{tabular}

As shown in Table 1, the average daily consumptions of a household, shop and school were found to be $4.73 \mathrm{kWh} / \mathrm{day}$, $3.67 \mathrm{kWh} /$ day and $4.2 \mathrm{kWh} /$ day respectively. The average daily consumption of whole village was calculated to be $367 \mathrm{kWh} /$ day with peak load of $37.6 \mathrm{~kW}$.

In Figure 5, the hourly load profile for 24 hours is shown. The daily peak load is $13 \mathrm{~kW}$ that usually occurs for 2 hours (i.e. from $10 \mathrm{am}$ to $11 \mathrm{am}$ and from $2 \mathrm{pm}$ to $3 \mathrm{am})$. 


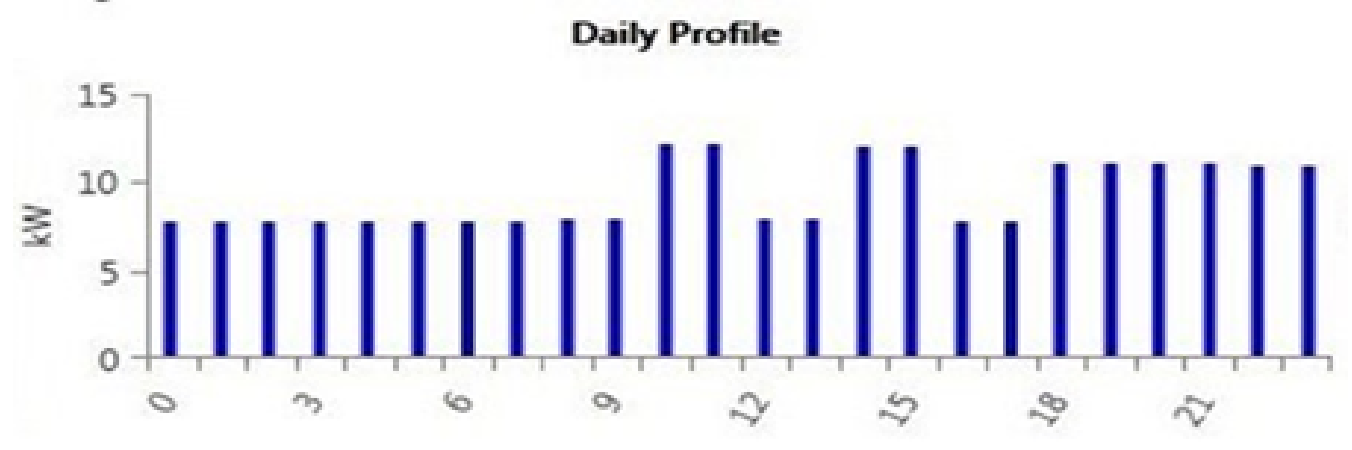

Fig 5. Hourly load profile

\subsection{System description and modeling}

Solar PV Panel of JINCO Solar Company with a power rating of 275 watts is selected because of its low cost and mid-range efficiency and life of 25 years. Generic Wind Turbine Generator (WTG) of $1 \mathrm{~kW}$ with turbine height of $25 \mathrm{~m}$ and life of 20 years is selected. To make a suitable Hybrid System we have assumed WTG sizes as $20 \mathrm{~kW}, 30 \mathrm{~kW}, 40 \mathrm{~kW}, 50 \mathrm{~kW}$ and $60 \mathrm{~kW}$. HOMER will choose the optimum size from these values. The converter of $90 \%$ efficiency and 15 years of life cycle is used in this study.

The cost of Solar PV, WTG, Battery, Converter and Diesel Generator are obtained from the local Solar and Wind Turbine installation companies of Pakistan whereas the cost and specifications of Hydrogen FC, Electrolyzer and Hydrogen Tank are taken from ${ }^{(9)}$. This system is designed for 25 years life span. All cost values are taken in Pakistani Rupees (PKR) and all the calculations are done in Pakistani Rupees (PKR) for accuracy purpose.

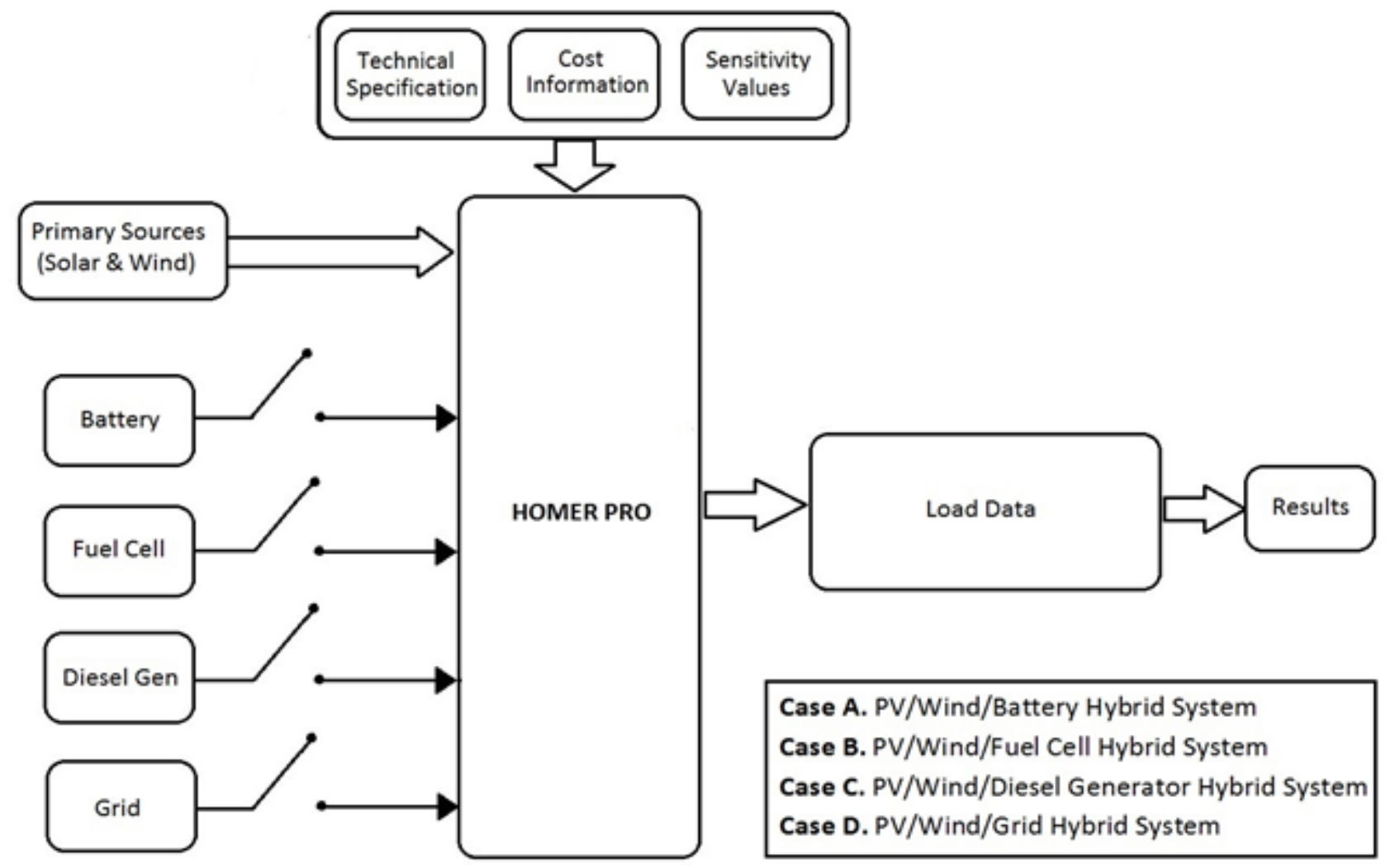

Fig 6. Block diagram 
As shown in the Block Diagram in Figure 6, Solar PV and Wind Turbine are the primary sources in all models and the backup sources includes a battery, hydrogen fuel cell, diesel generator and grid supply. These backup techniques are integrated one by one with primary sources to investigate all four hybrid cases and to find the most optimum hybrid system configuration for each case.

Case A. PV/Wind/Battery Hybrid System

This hybrid system consists of two renewable sources Solar PV, Wind Turbine Generator and a battery for storage purpose as shown in Figure 7. A 12V, 83Ah lead-acid battery with maximum 3 years of life cycle is selected in this system.

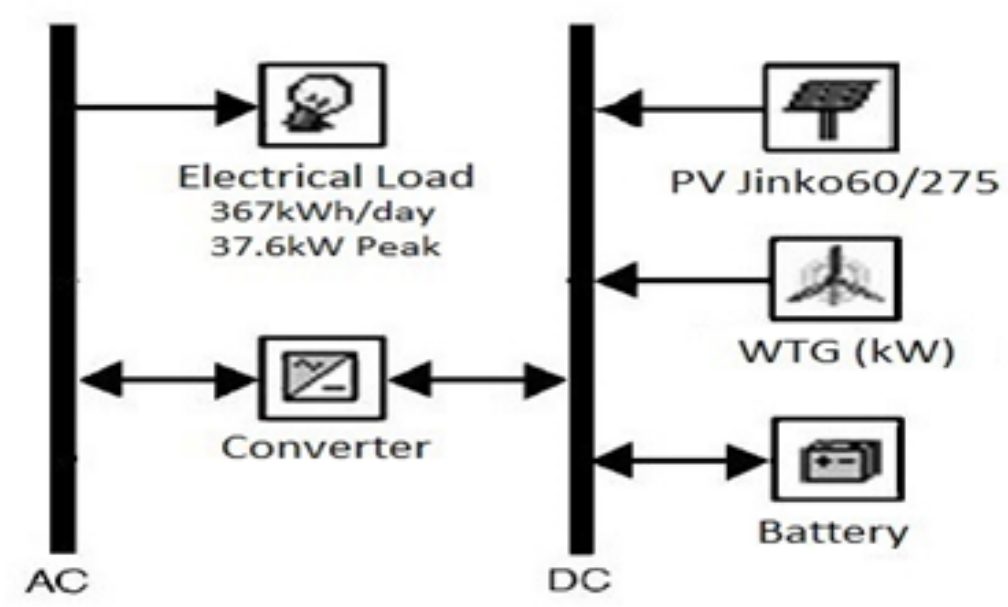

Fig 7. PV/Wind/Battery based hybrid microgrid system

Case B. PV/Wind/Hydrogen fuel cell hybrid system

In this hybrid system, Hydrogen FC is integrated with Solar PV and WTG sources for storage purpose a scan be seen in Figure 8. For the low power application (i.e. less than $100 \mathrm{~kW}$ ) the most preferred technology to generate Hydrogen is Proton Exchange Membrane (PEM) ${ }^{(9)}$. It has three components, Electrolyzer to generate hydrogen from water, Hydrogen Tank to store that hydrogen in a compressed form and a Fuel Cell to generate electricity from that hydrogen when required. The sizes of Hydrogen Tank are assumed as $(30 \mathrm{~kg}, 40 \mathrm{~kg}, 50 \mathrm{~kg}$ and $60 \mathrm{~kg})$, for Hydrogen FC as (10kW, 20kW, 30kW and $40 \mathrm{~kW})$ and for Electrolyzer as $(40 \mathrm{~kW}, 50 \mathrm{~kW}, 60 \mathrm{~kW}$ and $70 \mathrm{~kW})$. HOMER will choose the optimum size for each component.

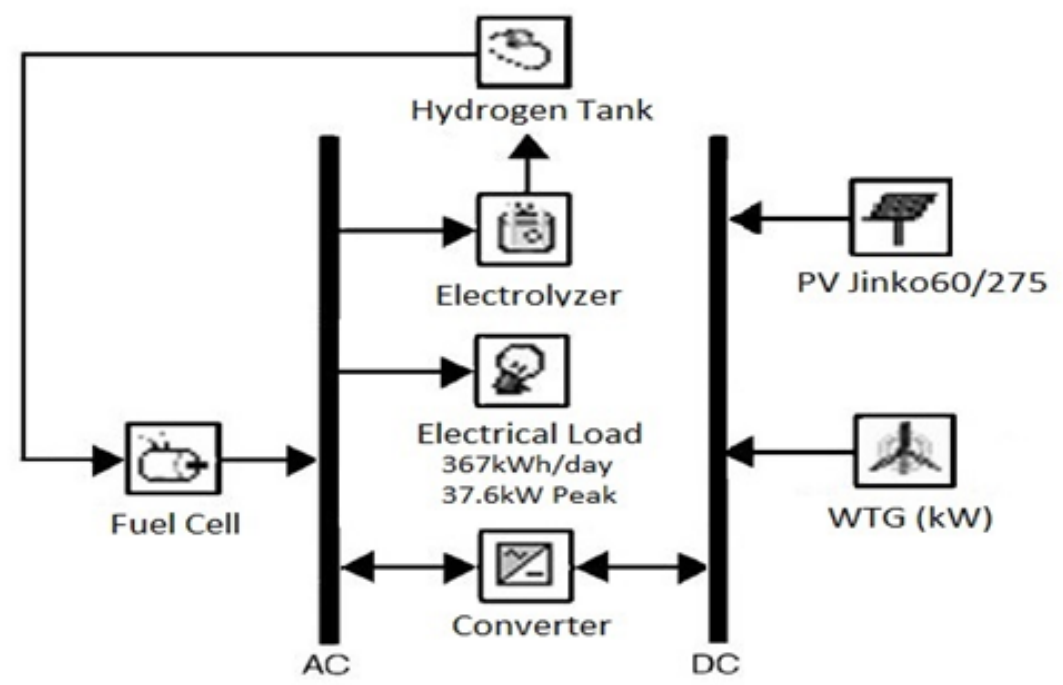

Fig 8. PV/Wind/Hydrogen FC based hybrid microgrid system 
Case C. PV/Wind/Diesel generator hybrid system

This hybrid system involves a diesel generator as a backup source with Solar PV and WTG sources as shown in Figure 9. Diesel Generator sizes are assumed as (10kW, 20kW, 30kW and 40kW), HOMER will choose the optimum size from these values. The sensitivity analysis is performed on this system due to the variation in diesel fuel prices every year. The sensitivity values in terms of diesel fuel prices are taken as PKR 124/liter and PKR 128/liter.

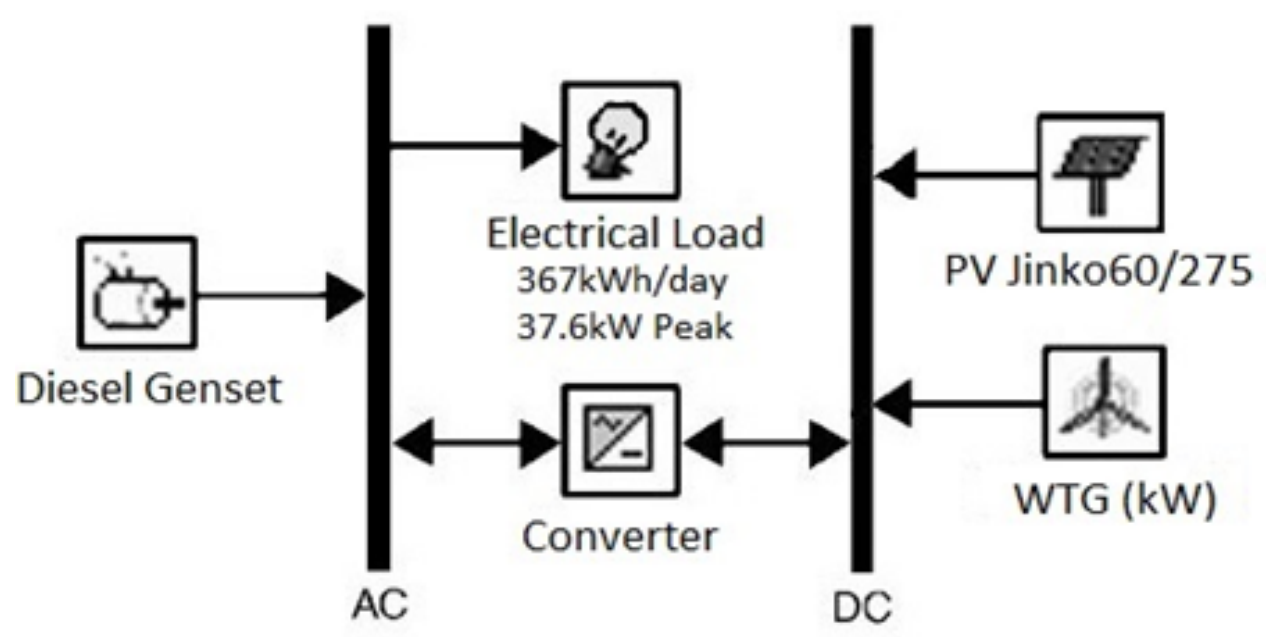

Fig 9. PV/Wind/DG Based Hybrid Microgrid System

Case D. PV/Wind/Grid hybrid system

This hybrid system contains Solar PV and WTG along with a Grid connection for backup power supply as can be seen in Figure 10. The Grid supplies power when the demand exceeds the supply coming from renewable sources. The sensitivity analysis is performed on this system due to variation in the unit cost over the units consumption. The sensitivity values in terms of Grid unit prices are taken as PKR 17/kWh and PKR 25/kWh.

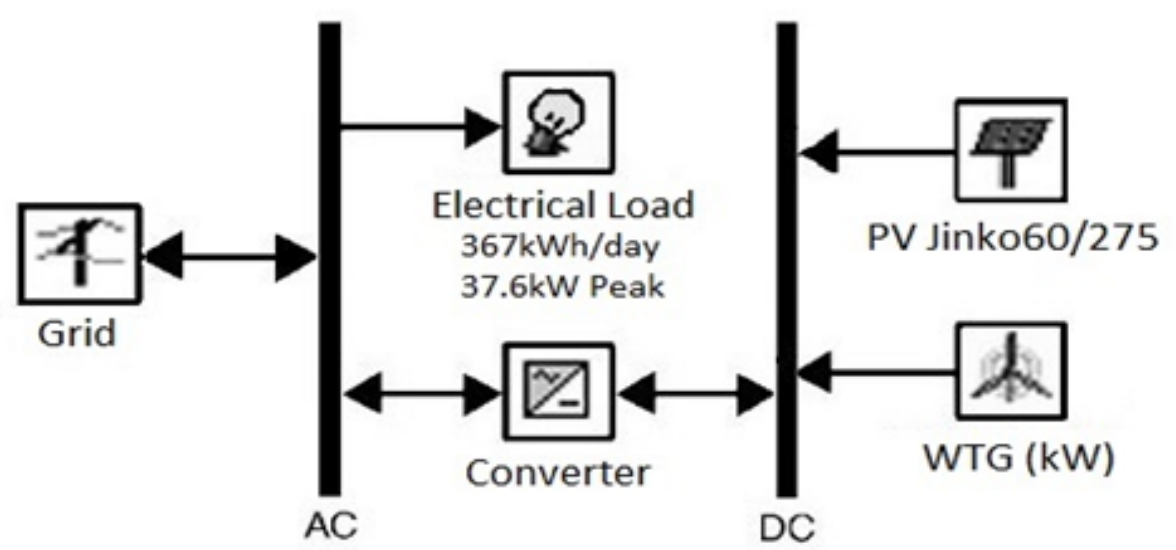

Fig 10. PV/Wind/Grid based hybrid microgrid system 


\section{Results and Discussion}

HOMER performed the optimization during the simulation period on all four hybrid systems based on the given inputs and showed the number of possible system configurations on the basis of NPC and COE.

\subsection{Simulation Results}

Case A. PV/Wind/Battery hybrid system

HOMER performed optimization on this hybrid model and provide the optimal results based on given inputs ( Table 2).

Table 2. PV/Wind/Battery system results

\begin{tabular}{|c|c|c|c|c|c|c|c|c|c|c|c|}
\hline $\begin{array}{l}\text { S. } \\
\#\end{array}$ & $\begin{array}{l}\text { Solar PV } \\
(\mathrm{kW})\end{array}$ & $\begin{array}{l}\text { WTG } \\
(\mathrm{kW})\end{array}$ & $\begin{array}{l}1 \mathrm{kWh} \\
\mathrm{LA}\end{array}$ & $\begin{array}{l}\text { Converter } \\
(\mathrm{kW})\end{array}$ & Dispatch & $\begin{array}{l}\mathrm{COE} \\
(\mathrm{PKR})\end{array}$ & $\begin{array}{l}\text { NPC } \\
(\mathrm{PKR})\end{array}$ & $\begin{array}{l}\text { Operating cost } \\
(\mathrm{PKR} / \mathrm{yr})\end{array}$ & $\begin{array}{l}\text { Initial capi- } \\
\text { tal (PKR) }\end{array}$ & $\begin{array}{l}\text { O\&M } \\
(\mathrm{PKR} / \mathrm{yr})\end{array}$ & $\begin{array}{l}\text { Ren } \\
\text { Frac } \\
(\%)\end{array}$ \\
\hline 1 & 276 & 40 & 512 & 37 & LF & 34.74 & $50.3 \mathrm{M}$ & $1.79 \mathrm{M}$ & $31 \mathrm{M}$ & 194400 & 100 \\
\hline 2 & 276 & 40 & 512 & 37 & CC & 34.74 & $50.3 \mathrm{M}$ & $1.79 \mathrm{M}$ & $31 \mathrm{M}$ & 194400 & 100 \\
\hline 3 & 278 & 40 & 508 & 39 & LF & 34.77 & $50.4 \mathrm{M}$ & $1.78 \mathrm{M}$ & $31 \mathrm{M}$ & 194400 & 100 \\
\hline 4 & 278 & 40 & 508 & 39 & $\mathrm{CC}$ & 34.77 & $50.4 \mathrm{M}$ & $1.78 \mathrm{M}$ & $31 \mathrm{M}$ & 194400 & 100 \\
\hline 5 & 236 & 50 & 511 & 48 & LF & 34.82 & $50.4 \mathrm{M}$ & $1.85 \mathrm{M}$ & $30.4 \mathrm{M}$ & 243000 & 100 \\
\hline 6 & 236 & 50 & 511 & 48 & $\mathrm{CC}$ & 34.82 & $50.4 \mathrm{M}$ & $1.85 \mathrm{M}$ & $30.4 \mathrm{M}$ & 243000 & 100 \\
\hline 7 & 235 & 50 & 512 & 47 & LF & 34.82 & $50.4 \mathrm{M}$ & $1.86 \mathrm{M}$ & $30.3 \mathrm{M}$ & 243000 & 100 \\
\hline
\end{tabular}

The simulation results for this hybrid system show that the optimal design contains 276kW Solar PV, 40kW WTG, 512 Batteries and 37.3kW Converter. The NPC of this optimal hybrid system for 25 years is PKR 50.3M and COE is PKR 34.74 . This hybrid system is completely renewable with $100 \%$ Renewable Fraction. The replacement cost of batteries in this system is high as compared to other components.

Case B. PV/Wind/Hydrogen fuel cell hybrid system

The optimization is performed by the HOMER on this hybrid model based on given inputs and then optimal results are provided ( Table 3).

Table 3. PV/Wind/Hydrogen FC system results

\begin{tabular}{|c|c|c|c|c|c|c|c|c|c|c|c|c|c|}
\hline $\begin{array}{l}\text { S. } \\
\#\end{array}$ & $\begin{array}{l}\text { Solar } \\
\text { PV } \\
(\mathrm{kW})\end{array}$ & $\begin{array}{l}\text { WTG } \\
(\mathrm{kW})\end{array}$ & $\begin{array}{l}\text { FC } \\
(\mathrm{kW})\end{array}$ & $\begin{array}{l}\text { Electrolyzer } \\
(\mathrm{kW})\end{array}$ & $\begin{array}{l}\text { H.Tank } \\
(\mathrm{kg})\end{array}$ & $\begin{array}{l}\text { Converter } \\
(\mathrm{kW})\end{array}$ & Dispat & $\begin{array}{l}\text { cKOE } \\
(\mathrm{PKR})\end{array}$ & $\begin{array}{l}\text { NPC } \\
\text { (PKR) }\end{array}$ & $\begin{array}{l}\text { Operating } \\
\text { cost } \\
(\mathrm{PKR} / \mathrm{yr})\end{array}$ & $\begin{array}{l}\text { Initial } \\
\text { capital } \\
\text { (PKR) }\end{array}$ & $\begin{array}{l}\text { O\&M } \\
(\mathrm{PKR} / \mathrm{yr})\end{array}$ & $\begin{array}{l}\text { Ren } \\
\text { Frac } \\
(\%)\end{array}$ \\
\hline 1 & 224 & 60 & 30 & 60 & 60 & 36 & LF & 54.56 & $79.1 \mathrm{M}$ & $2.53 \mathrm{M}$ & $51.7 \mathrm{M}$ & 1986840 & 100 \\
\hline 2 & 224 & 60 & 30 & 60 & 60 & 36 & $\mathrm{CC}$ & 54.56 & $79.1 \mathrm{M}$ & $2.53 \mathrm{M}$ & $51.7 \mathrm{M}$ & 1986840 & 100 \\
\hline 3 & 226 & 60 & 30 & 60 & 60 & 34 & LF & 54.62 & $79.2 \mathrm{M}$ & $2.53 \mathrm{M}$ & $51.8 \mathrm{M}$ & 1987200 & 100 \\
\hline 4 & 226 & 60 & 30 & 60 & 60 & 34 & CC & 54.62 & $79.2 \mathrm{M}$ & $2.53 \mathrm{M}$ & $51.8 \mathrm{M}$ & 1987200 & 100 \\
\hline 5 & 226 & 60 & 30 & 60 & 60 & 35 & LF & 54.63 & $79.2 \mathrm{M}$ & $2.53 \mathrm{M}$ & $51.8 \mathrm{M}$ & 1987200 & 100 \\
\hline 6 & 226 & 60 & 30 & 60 & 60 & 35 & $\mathrm{CC}$ & 54.63 & $79.2 \mathrm{M}$ & $2.53 \mathrm{M}$ & $51.8 \mathrm{M}$ & 1987200 & 100 \\
\hline 7 & 238 & 60 & 30 & 60 & 50 & 35 & LF & 54.63 & $79.2 \mathrm{M}$ & $2.52 \mathrm{M}$ & $51.9 \mathrm{M}$ & 1982520 & 100 \\
\hline
\end{tabular}

The simulation results for this hybrid system show that the optimal design consists of 224kW Solar PV, 60kW WTG, 36kW Converter, 30kW Hydrogen FC, 60kW Electrolyzer and 60kg Hydrogen Tank. The NPC of this system is PKR 79.1M and COE PKR 54.56. This system has $100 \%$ Renewable Fraction

Case C. PV/Wind/Diesel generator hybrid system

In this hybrid system, HOMER performed optimization method on two models with different sensitivity values for diesel fuel prices (i.e. PKR 124/L and PKR 128/L) and provided two optimized results based on those sensitivity values ( Table 4). 
Table 4. PV/Wind/DG system results

\begin{tabular}{|c|c|c|c|c|c|c|c|c|c|c|c|c|c|}
\hline $\begin{array}{l}\text { S. } \\
\#\end{array}$ & $\begin{array}{l}\text { Diesel } \\
\text { Fuel Price } \\
(\mathrm{PKR} / \mathrm{L})\end{array}$ & $\begin{array}{l}\text { Solar } \\
\text { PV } \\
(\mathrm{kW})\end{array}$ & $\begin{array}{l}\text { WTG } \\
(\mathrm{kW})\end{array}$ & $\begin{array}{l}\text { DG } \\
(\mathrm{kW})\end{array}$ & $\begin{array}{l}\text { Converter } \\
(\mathrm{kW})\end{array}$ & Dispatch & $\begin{array}{l}\text { COE } \\
\text { (PKR) }\end{array}$ & $\begin{array}{l}\text { NPC } \\
(\mathrm{PKR})\end{array}$ & $\begin{array}{l}\text { Operating } \\
\text { cost } \\
(\mathrm{PKR} / \mathrm{yr})\end{array}$ & $\begin{array}{l}\text { Initial } \\
\text { capital } \\
\text { (PKR) }\end{array}$ & $\begin{array}{l}\text { Fuel } \\
\text { cost } \\
(\mathrm{PKR} / \mathrm{yr})\end{array}$ & $\begin{array}{l}\text { O\&M } \\
(\mathrm{PKR} / \mathrm{yr})\end{array}$ & $\begin{array}{l}\text { Ren } \\
\text { Frac (\%) }\end{array}$ \\
\hline 1 & 124 & 84 & 40 & 30 & 35 & $\mathrm{CC}$ & 42.11 & $61 \mathrm{M}$ & $4.31 \mathrm{M}$ & $14.4 \mathrm{M}$ & $3.08 \mathrm{M}$ & 883062 & 61.1 \\
\hline 2 & 128 & 84 & 40 & 30 & 35 & $\mathrm{CC}$ & 42.85 & $62.1 \mathrm{M}$ & $4.41 \mathrm{M}$ & $14.4 \mathrm{M}$ & $3.17 \mathrm{M}$ & 883062 & 61.1 \\
\hline 3 & 124 & 84 & 40 & 30 & 35 & LF & 42.11 & $61 \mathrm{M}$ & $4.31 \mathrm{M}$ & $14.4 \mathrm{M}$ & $3.08 \mathrm{M}$ & 883062 & 61.1 \\
\hline 4 & 124 & 84 & 40 & 30 & 35 & $\mathrm{CC}$ & 42.11 & $61 \mathrm{M}$ & $4.31 \mathrm{M}$ & $14.4 \mathrm{M}$ & $3.08 \mathrm{M}$ & 883062 & 61.1 \\
\hline 5 & 124 & 84 & 40 & 30 & 34 & LF & 42.12 & $61 \mathrm{M}$ & $4.31 \mathrm{M}$ & $14.4 \mathrm{M}$ & $3.08 \mathrm{M}$ & 883623.6 & 61.1 \\
\hline 6 & 128 & 84 & 40 & 30 & 35 & LF & 42.85 & $62.1 \mathrm{M}$ & $4.41 \mathrm{M}$ & $14.4 \mathrm{M}$ & $3.17 \mathrm{M}$ & 883062 & 61.1 \\
\hline 7 & 128 & 84 & 40 & 30 & 35 & $\mathrm{CC}$ & 42.85 & $62.1 \mathrm{M}$ & $4.41 \mathrm{M}$ & $14.4 \mathrm{M}$ & $3.17 \mathrm{M}$ & 883062 & 61.1 \\
\hline 8 & 128 & 84 & 40 & 30 & 34 & LF & 42.85 & $62.1 \mathrm{M}$ & $4.41 \mathrm{M}$ & $14.4 \mathrm{M}$ & $3.17 \mathrm{M}$ & 883623.6 & 61.1 \\
\hline
\end{tabular}

The simulation results for both fuel prices (i.e. PKR 124/L and PKR 128/L) show that the optimal design contains $84.3 \mathrm{~kW}$ Solar PV, 40kW WTG, 35kW Converter and 30kW Diesel Generator. The NPC and COE for fuel price PKR 124/L are PKR 61M and COE PKR 42.11 respectively. For fuel price PKR 128/L, the NPC and COE are PKR 62.1M and PKR 42.85. The renewable fraction for both cases is $61.1 \%$.

Case D. PV/Wind/Grid hybrid system

In this hybrid system, the optimization is performed on two models with different sensitivity values for Grid unit prices (i.e PKR 17/kWh and 25/kWh). As shown in Table 5.

Table 5. PV/Wind/Grid system results

\begin{tabular}{|c|c|c|c|c|c|c|c|c|c|c|c|c|}
\hline S. \# & $\begin{array}{l}\text { Power } \\
\text { Price } \\
(\mathrm{PKR} / \mathrm{kWh})\end{array}$ & $\begin{array}{l}\text { Solar } \\
\text { PV } \\
(\mathrm{kW})\end{array}$ & $\begin{array}{l}\text { WTG } \\
(\mathrm{kW})\end{array}$ & $\begin{array}{l}\text { Grid } \\
(\mathrm{kW})\end{array}$ & $\begin{array}{l}\text { Conv } \\
(\mathrm{kW})\end{array}$ & Dispatch & $\begin{array}{l}\mathrm{COE} \\
(\mathrm{PKR})\end{array}$ & $\begin{array}{l}\text { NPC } \\
\text { (PKR) }\end{array}$ & $\begin{array}{l}\text { Operating } \\
\text { cost } \\
(\mathrm{PKR} / \mathrm{yr})\end{array}$ & $\begin{array}{l}\text { Initial } \\
\text { capital } \\
\text { (PKR) }\end{array}$ & $\begin{array}{l}\text { O\&M } \\
(\mathrm{PKR} / \mathrm{yr})\end{array}$ & $\begin{array}{l}\text { Ren } \\
\text { Frac } \\
(\%)\end{array}$ \\
\hline 1 & 17 & 39 & 20 & 999999 & 24 & $\mathrm{CC}$ & 12.84 & $21 \mathrm{M}$ & $1.32 \mathrm{M}$ & $6.63 \mathrm{M}$ & $1.28 \mathrm{M}$ & 53.9 \\
\hline 2 & 25 & 46 & 20 & 999999 & 26 & $\mathrm{CC}$ & 15.91 & $26.9 \mathrm{M}$ & $1.83 \mathrm{M}$ & $7.11 \mathrm{M}$ & $1.78 \mathrm{M}$ & 56.8 \\
\hline 3 & 17 & 39 & 20 & 999999 & 24 & LF & 12.84 & $21 \mathrm{M}$ & $1.32 \mathrm{M}$ & $6.63 \mathrm{M}$ & $1.28 \mathrm{M}$ & 53.8 \\
\hline 4 & 17 & 39 & 20 & 999999 & 24 & CC & 12.84 & $21 \mathrm{M}$ & $1.32 \mathrm{M}$ & $6.63 \mathrm{M}$ & $1.28 \mathrm{M}$ & 53.8 \\
\hline 5 & 17 & 37 & 20 & 999999 & 23.8 & $\mathrm{LF}$ & 12.95 & $21 \mathrm{M}$ & $1.33 \mathrm{M}$ & $6.5 \mathrm{M}$ & $1.29 \mathrm{M}$ & 52.9 \\
\hline 6 & 25 & 46 & 20 & 999999 & 26 & $\mathrm{LF}$ & 15.91 & $26.9 \mathrm{M}$ & $1.83 \mathrm{M}$ & $7.1 \mathrm{M}$ & $1.78 \mathrm{M}$ & 56.8 \\
\hline 7 & 25 & 46 & 20 & 999999 & 26 & $\mathrm{CC}$ & 15.91 & $26.9 \mathrm{M}$ & $1.83 \mathrm{M}$ & $7.1 \mathrm{M}$ & $1.78 \mathrm{M}$ & 56.8 \\
\hline 8 & 25 & 48 & 20 & 999999 & 26 & LF & 15.8 & $26.9 \mathrm{M}$ & $1.81 \mathrm{M}$ & $7.2 \mathrm{M}$ & $1.77 \mathrm{M}$ & 57.4 \\
\hline
\end{tabular}

The optimized system design with Grid price PKR 17/kWh has 39.1kW Solar PV, 20kW WTG, 24.2kW Converter with NPC PKR 21M and COE PKR 12.84. For the unit price of PKR 25/kWh the system design contains 46kW Solar PV, 20kW WTG and 26.1kW Converter with NPC PKR 26.9M and COE PKR 15.92 as can be seen in the Simulation Results in Table 5. The Renewable Fraction in 1 st case is $53.9 \%$ and in 2 nd case it is $56.8 \%$.

\subsection{Comparison of all hybrid system cases}

Figure 11 shows the comparison of all four optimal hybrid cases configurations obtained from the results on the basis of NPC, COE and Renewable Fraction (RF). The NPC value is expressed in Million Pakistani Rupees (PKR) whereas the COE is expressed in simple Pakistani Rupees. The renewable fraction (RF) is shown in percentage (\%) form and its values are shown on the right side of comparison chart. 


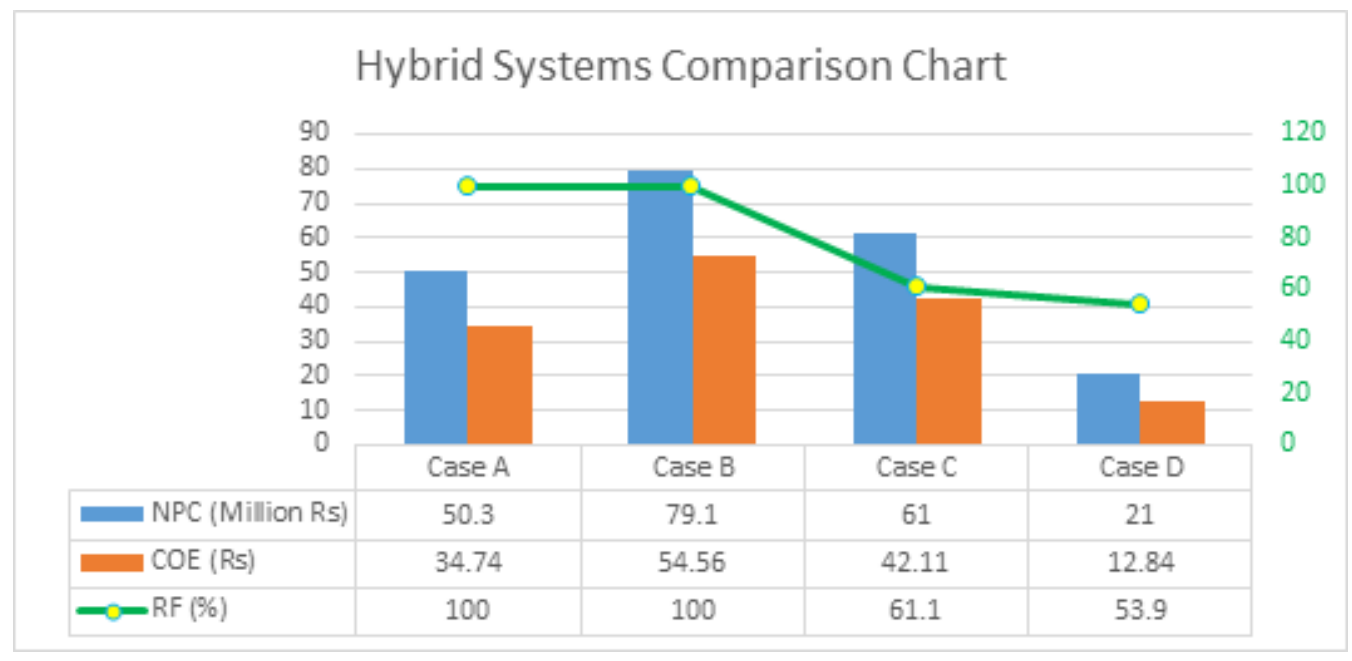

Fig 11. Hybrid systems comparison chart

\section{Conclusion}

In this study, four hybrid systems involving two common primary sources Solar and Wind along with different backup sources which have been designed and optimized with the help of HOMER. Then, a comparative analysis is carried out on all the possible system configurations obtained from HOMER based on NPC and COE to find the most optimal hybrid system with minimum NPC and COE. After the comparison of all optimum hybrid cases as shown in Figure 11, it is found that the most optimal and least cost hybrid system is Case D. PV/Wind/Grid hybrid system with NPC PKR 21M and COE PKR 12.84. The payback period of this hybrid system is 4.25 years. The 2nd optimal but little expensive system is Case A. PV/Wind/Battery Hybrid System with NPC PKR 50.3M and COE PKR 34.74. This hybrid system is $100 \%$ renewable and has payback period of 2.96 years. The Case B. PV/Wind/Hydrogen FC Hybrid System and Case C. PV/Wind/DG Hybrid System are the most expensive and unfeasible hybrid systems due to the high capital cost and operating cost of Hydrogen Fuel Cell Components and Diesel Generator Respectively. Moreover, the surplus energy produced from the Grid connected optimal Hybrid System can be sold back to the National Grid at a specific price and this may further reduce the NPC and COE of the system.

\section{Acknowledgement}

Authors would like to acknowledge Mehran University of Engineering and Technology (MUET), Jamshoro, Pakistan for providing necessary resources and guidance.

\section{References}

1) International Energy Agency News. 2019. Available from: https://www.iea.org/news/global-energy-demand-rose-by-23-in-2018-its-fastest-pace-in-thelast-decade.

2) Kamran M, Asghar R, Mudassar M, Ahmed SR, Fazal MR, Abid MI, et al. Designing and Optimization of Stand-alone Hybrid Renewable Energy System for Rural Areas of. Internationa Journal of Renewable Energy Research. 2018;8(4):2385-2397. Available from: https://pdfs.semanticscholar.org/cf0d/ 8a730899f98f1be19e39c4365a4a5e4cb7e0.pdf.

3) Pakistan's Energy Survey Report. 2019. Available from: http://www.finance.gov.pk/survey/chapters_19/14-Energy.pdf.

4) Iqbal A, Iqbal MT. Design and Analysis of a Stand-Alone PV System for a Rural House in Pakistan. International Journal of Photoenergy. 2019;2019:1-8. Available from: https://dx.doi.org/10.1155/2019/4967148.

5) Li C, Zhou D, Wang H, Lu Y, Li D. Techno-economic performance study of stand-alone wind/diesel/battery hybrid system with different battery technologies in the cold region of China. Energy. 2020. Available from: https://doi.org/10.1016/j.energy.2019.116702.

6) Nawaz MA, Raheem A, Anwar Z. Feasibility and Optimization of Standalone PV/Biogas Hybrid Distributed Renewable System for Rural Electrification: A Case Study of a Cholistan Community. Mehran University Research Journal of Engineering and Technology. 2019;38(2):453-462. Available from: https://doi.org/10.22581/muet1982.1902.19.

7) Kazmi SWS, Sheikh MI. Hybrid geothermal-PV-wind system for a village in Pakistan. SN Applied Sciences. 2019;1(7). Available from: https: //dx.doi.org/10.1007/s42452-019-0643-9.

8) Google Maps .2020. Available from: https://www.google.com/maps/@25.1190532,68.536639,2700m/data=!3m1!1e3.

9) NASA Surface Meteorology and Solar Energy Database. . Available from: https://power.larc.nasa.gov/. 